Avoimesti luettavissa osoitteessa http://journal.fi/ainedidaktiikka

ainedidaktiikka

\title{
Monimateriaalisuus perusopetuksen käsityössä
}

\author{
Sinikka Pöllänen ${ }^{1}$, Marja-Leena Rönkkö ${ }^{2}$, Anssi Salonen ${ }^{1}$, Tellervo Härkki ${ }^{3}$ ja Eila Lindfors ${ }^{2}$ \\ ${ }^{1}$ Filosofinen tiedekunta, Itä-Suomen yliopisto \\ ${ }^{2}$ Kasvatustieteiden tiedekunta, Turun yliopisto \\ ${ }^{3}$ Kasvatustieteellinen tiedekunta, Helsingin yliopisto
}

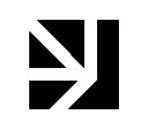

Peruskoulun käsityö on monimateriaalinen oppiaine, jonka sisältöjä ja toimintaa tukevat sekä teknisen työn että tekstiilityön työtavat. Perusopetuksen opetussuunnitelman perusteiden mukaan käsityön tehtävänä on ohjata oppilaita kokonaisen käsityöprosessin hallintaan. Kokonaista käsityöprosessia ja monimateriaalisuutta toteuttava käsityö on kuitenkin koettu epäselväksi ja vaikeaksi toteuttaa. Ongelmalliseksi on koettu resurssien rajallisuus sekä se, että teknisen työn ja tekstiilityön työtapojen oppimisympäristöt sijaitsevat usein erillään toisistaan. Lisäksi käsityötä opettavien koulutustausta ja perehtyneisyys eri käsityön työtapoihin on vaihteleva riippuen opintojen sisällöistä ja harrastuneisuudesta. Tämän kuvailevan kirjallisuuskatsauksen tavoitteena on konkretisoida esimerkein pedagogisia lähtökohtia käsityön monimateriaalisuuteen. Näiden lähtökohtien taustoittamiseksi kuvataan myös käsityöoppiaineen opetuksen organisoinnissa tapahtuneita muntoksia ja avataan monimateriaalisuuden käsitettä sekä siihen liittyviä reunaehtoja. Monimateriaalisuntta kuvaavissa pedagogisissa esimerkeissä on nostettu esiin, miten monimateriaalisuus näyttäytyy opiskeltavana sisältönä ja miten se välittyy oppilaille yksin tai yhdessä työskenneltäessä.

Monimateriaalinen, kokonainen käsityöprosessi, käsityön opetus, perusopetus

Lähetetty: 15.3.2020

Hyväksytty: 29.10.2020

Vastuukirjoittaja: sinikka.pollanen@uef.fi

DOI: $10.23988 / \mathrm{ad} .90017$ 


\section{Johdanto}

Valtioneuvoston asetuksen (Valtioneuvosto, 2012) sisältämän tuntijaon mukaan käsityötä opiskellaan peruskoulussa vuosiluokilla 1-9. Lähtökohtana on, että kaikki oppilaat opiskelevat perusopetuksen aikana käsityön sisältöjä tasapuolisesti. Opetuksen järjestäjälle jää asetuksen mukaisesti mahdollisuus sijoittaa kaikille yhteisiä tunteja eri vuosiluokilla määriteltyjen vähimmäistuntien sallimissa rajoissa sekä osoittaa opetukseen tuntijakoa enemmän tunteja. Asetuksen mukaista vähimmäistuntimäärää ei kuitenkaan saa alittaa. Kaikille yhteisten tuntien lisäksi opetuksen järjestäjä voi päättää käsityön ja taide- ja taitoaineiden valinnaisten tuntien määrästä oppiaineittain ja niiden sijoittamisesta perusasteen alimmilla ja ylimmillä vuosiluokilla. Tällöin oppilaalla voi olla mahdollisuus opiskella käsityötä myös valinnaisaineena.

Perusopetuksen opetussuunnitelman perusteiden (Opetushallitus, 2014) mukaan käsityön opetuksen sisältönä ovat oppilaan kiinnostuksen kohteista ja tarpeista nouseva kokonainen käsityöprosessi, tekstiilityön ja teknisen työn työtavat sekä entisestään laajenevat digitaalitekniikkaan perustuvat teknologiat. Kokonaiseen käsityöprosessiin tähtäävät tavoitteet on tarkoitus toteuttaa monimateriaalisesti, käsityöilmaisuun, muotoiluun ja teknologiaan perustuvan toiminnan avulla.

Perusopetuksen opetussuunnitelman perusteiden (Opetushallitus, 2014) mukaan käsityössä opetellaan ymmärtämään, arvioimaan ja kehittämään erilaisia teknologisia sovelluksia sekä käyttämään opittuja tietoja ja taitoja arjessa. Tavoitteena on vahvistaa oppilaiden monipuolista työskentelyä, jolloin merkityksen nähdään olevan suunnitteluosaamisen sisältävässä pitkäjänteisessä ja innovatiivisessa työskentelyprosessissa. Käsityön tavoitteena on myös lisätä tuntemusta ympäröivästä materiaalisesta maailmasta, jolloin voidaan luoda perustaa kestävän kehityksen mukaiselle elämäntavalle.

Käsityön tulee perusopetuksen opetussuunnitelman perusteiden (Opetushallitus, 2014) mukaan olla tutkivaa, keksivää ja kokeilevaa niin, että siinä toteutetaan erilaisia visuaalisia, materiaalisia, teknisiä ja valmistusmenetelmällisiä ratkaisuja. Opetussuunnitelma ei siis anna ohjeita käsitöiden valmistamisesta tai pedagogisista ratkaisuista eikä tarkemmin määrittele opetettavia ja opetuksessa hyödynnettäviä materiaaleja, työtapoja, tekniikoita tai teknologioita. Sen sijaan opetuksessa tulee huomioida oppijoiden erilaiset kiinnostuksen kohteet ja yhteisöllinen toiminta sekä laaja-alaisten oppiaineet ylittävien teemojen kokonaisvaltainen tarkastelu (Opetushallitus, 2014).

Perusopetuksen opetussuunnitelman perusteiden (Opetushallitus, 2014) uudistamista edelsi laaja, myös internetissä avoin, julkinen keskustelu perusopetuksen tulevaisuuden näkymistä. Perusopetuksen ja myös kädentaitojen osalta lähtökohtana pidettiin yleissivistystä, jolloin oppiainetta päädyttiin kehittämään kaikille oppilaille yhteisesti toteutettavan käsityön pohjalta (Manninen \& Rissanen, 2019). Kokonaista käsityöprosessia ja monimateriaalisuutta toteuttava käsityö on kuitenkin koettu 
epäselväksi ja vaikeaksi toteuttaa (Vuolas, 2017). Kokko, Kouhia ja Kangas (2020) kuvaavat haasteiksi myös erillään olevat käsityön oppimisympäristöt, lukujärjestystekniset aikataulutukset, rajalliset tuntimäärät ja muut resurssit suhteessa opetettaviin sisältöihin. Käsityön opetuksen toteutusta ohjaa opettajien ainedidaktinen koulutustausta teknisestä työstä tai tekstiilityöstä (Lindfors, Marjanen, \& Jaatinen, 2016), jolloin oppiaineessa on tavallisimmin kaksi eri opettajaa. Vuosien kuluessa jännitteet muotoilun ja teknologian välillä ovat kasvaneet (Marjanen \& Metsärinne, 2019), lisänneet kannanottoja (Hankala-Vuorinen, 2019; Ojanen \& Rastas, 2019) ja mediakeskustelua (Clavert \& Kangas ym., 2019; Grönholm, 2019; Sipola, 2019) sekä aiheuttaneet huolta nuorten riittävästä teknologiaosaamisesta ja motivaatiosta opiskella valinnaisaineena yhteiseksi käsityöoppiaineeksi muotoutunutta oppiainetta (Kallio \& Hilmola, 2019; Kokko ym., 2020). On pääteltävissä, että käsityöhön liitetty monimateriaalisuuden käsite on jäänyt epäselväksi ja aiheuttanut huolta siitä, että entiset käsityönopetuksessa toimiviksi todetut ratkaisut jouduttaisiin hylkäämään. Käsityön luontainen monimateriaalisuus on keskustelussa jäänyt vähälle huomiolle.

Tämän kuvailevan kirjallisuuskatsauksen tavoitteena on konkretisoida esimerkein pedagogisia lähtökohtia käsityön monimateriaalisuuteen. Näiden esimerkkien taustoittamiseksi kuvaamme ensin käsityöoppiaineen opetuksen organisoinnissa tapahtuneita muutoksia ja avaamme monimateriaalisuuden käsitettä sekä siihen liittyviä reunaehtoja.

\section{Käsityöoppiaineen taustaa}

Käsityö on useista muista maista poiketen ollut oma oppiaineensa suomalaisen koulujärjestelmän alusta alkaen (Reincke, 1995). Käsityöoppiaineen organisoinnin ja opetussuunnitelmaan liittyvät painopisteet ovat heijastelleet kunkin aikakauden koulutustarpeita sekä maan kulttuurista, poliittista ja taloudellista kehitystä (Garber, 2002; Kokko, 2007). Oppiaine on nimetty eri tavoin eri aikakausina, ja myös sen sisällöt ja tavoitteet ovat muuttuneet koulutusjärjestelmän kehityksen myötä (Marjanen \& Metsärinne, 2019). Sukupuolen mukaan eriytyneet oppiaineet ja oppisisällöt, tyttöjen ja poikien käsityöt (ks. kuvio 1) ohjasivat opetusta 1970-luvulle asti (Kokko, 2007; Lindfors, 2015; Lindfors ym., 2016; Marjanen, 2012).

Selkeä pyrkimys kohti kaikille oppilaille yhteistä käsityöoppiainetta on ollut näkyvissä 1970-luvulta lähtien (Marjanen, 2012), jolloin keskeisenä opetussuunnitelmaa kannattelevina lähtökohtina olivat oikeudenmukaisuus ja sukupuolten välinen tasa-arvo (Marjanen \& Metsärinne, 2019). Oppiaineen historia yhdessä koulujärjestelmään mutta myös laajemmin yhteiskuntaan juurtuneiden asenteiden kanssa ovat luoneet mielikuvaa siitä, että tekstiilityö ja tekninen työ olisivat olleet sukupuolittuneita oppiaineita, vaikka näin ei ole määritelty enää viiteenkymmeneen vuoteen. Vuoden 1994 opetussuunnitelman perusteet (Opetushallitus, 1994) määritteli oppiaineiden yhteiseksi nimeksi käsityön. Täydentävinä nimityksinä oppiaineelle säilyivät tekninen työ ja tekstiilityö (Marjanen, 2012). Askel kohti käsityöoppiaineen kehittymistä yhdeksi kaikille oppilaille yhteiseksi oppiaineeksi tehtiin perusopetuslaissa (1998), jossa tekninen työ ja tekstiilityö sisällytettiin käsityöoppiaineeseen. Seuraavissa 
opetussuunnitelman perusteissa oppiaineen nimenä perusopetuslain mukaisesti olikin käsityö (Opetushallitus, 2004). Vuoden 2004 perusopetuksen opetussuunnitelman perusteissa tekninen työ ja tekstiilityö määriteltiin käsityön sisältöalueiksi, jolloin ajatuksena oli tutustuttaa oppilaat erilaisiin käsityön materiaaleihin ja valmistusmenetelmiin. Oppilailla oli vuosiluokkien 1-4 yhteisen käsityön jälkeen mahdollisuus valita käsityön sisällöistä vuosiluokille 5-9 joko tekstiilityö tai tekninen työ oman kiinnostuksensa mukaisesti (Opetushallitus, 2004).

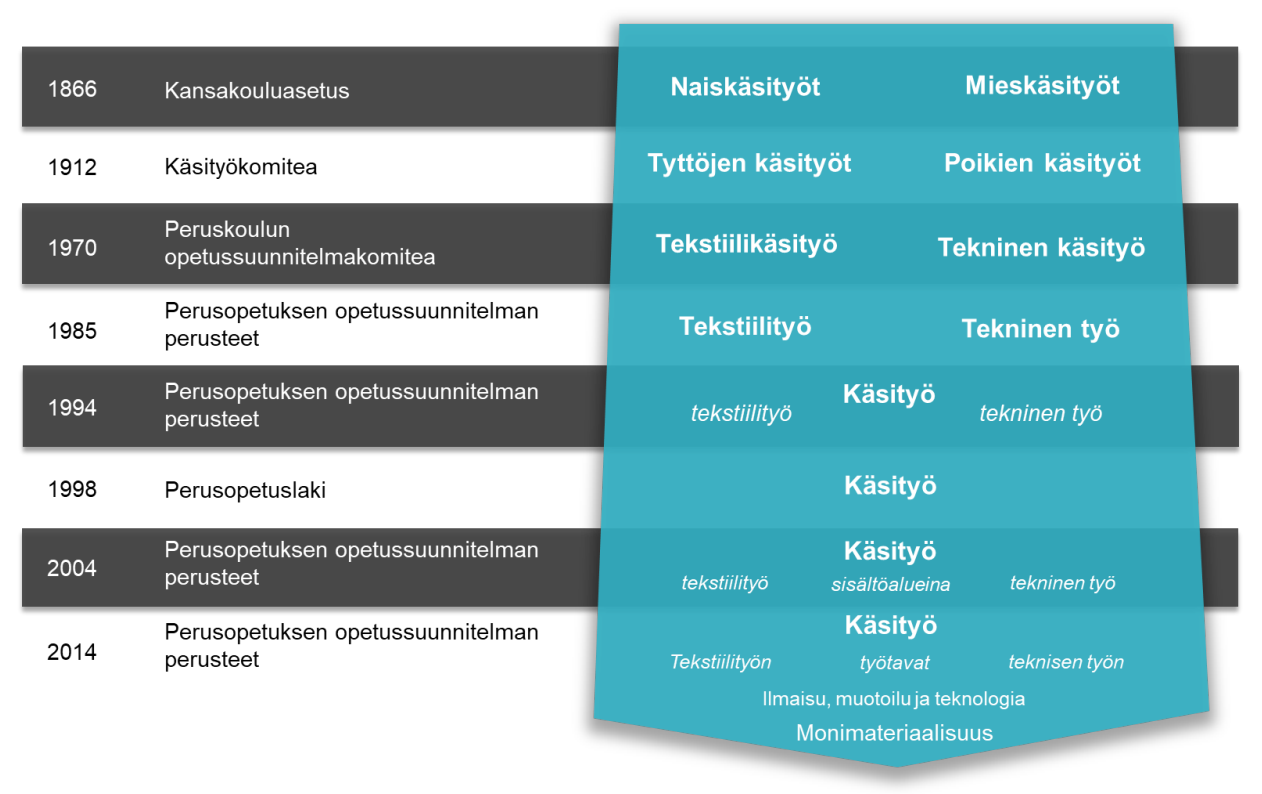

Kuvio 1. Käsityön oppiaineen kehittyminen vuosina 1866-2014 (mukaillen Lindfors, 2015; Lepistö \& Lindfors, 2015)

Perusopetuksen opetussuunnitelman perusteiden (Opetushallitus, 2014) mukaan käsityön tavoitteena on oppilaiden ohjaaminen kokonaisen käsityöprosessin hallintaan sisältäen innovatiivisen työskentelyn ja erilaisten teknologioiden ja työtapojen käytön. Käsityössä toteutetaan käsityöilmaisuun, muotoiluun ja teknologiaan perustuvaa toimintaa, jossa tekninen työ ja tekstiilityö säilyivät tutkivan, keksivän ja kokeilevan käsityön työtapoina (Opetushallitus, 2014). Kokonaisen käsityöprosessin toteuttamisen lisäksi oppiaineen keskeisiä tavoitteita ovat monipuolisen työskentelyn edellytysten vahvistaminen, opittujen tietojen ja taitojen soveltaminen arkeen, itsetunnon vahvistaminen sekä mielihyvän kokemusten tuottaminen (Porko-Hudd, Pöllänen, \& Lindfors, 2018). Opetussuunnitelmassa (Opetushallitus, 2014) ilmaistujen käsityön tavoitteiden mukaan oppilaita kannustetaan pitkäjänteiseen sekä innovatiiviseen työskentelyprosessiin, jossa yhdistellään ennakkoluulottomasti erilaisia visuaalisia, materiaalisia ja teknisiä ratkaisuja. Oppiaineen tehtävänä on kasvattaa oppilaista itseään arvostavia, eettisesti valveutuneita ja yritteliäitä käsityöntekijöitä, joilla on sekä halua ylläpitää ja kehittää käsityökulttuuria että taitoa käsityöilmaisuun. Käsityön opiskelu pohjautuu rakennetun elinympäristön ja materi- 
aalisen maailman havainnointiin, tutkimiseen ja soveltamiseen, jotta oppilaan tieto, taito ja arviointikyky teknologiaa ja ympäristöä kohtaan kehittyvät.

\section{Monimateriaalisuus käsitteenä}

Perusopetuksen opetussuunnitelman perusteissa (Opetushallitus, 2014) monimateriaalisuus on nostettu käsityön yhdeksi keskeiseksi käsitteeksi kokonaisen käsityöprosessin ohella. Monimateriaalisuus määrittelee oppiainetta kokonaisuutena, jolloin se ei määritä yksittäisiä käsityöprosesseja tai oppimistehtäviä. Monimateriaalisuus useiden erilaisten materiaalien yhdistämisenä ei siis ole itseisarvoinen tai uusi tavoite käsityössä, eikä se sisällä ohjeistusta siitä, miten käsityön suunnittelu- ja valmistusprosessi toteutetaan (Pöllänen, 2019). Käsityön monimateriaalisuus ei pyri luokittelemaan materiaaleja vaan ohjaamaan tarkastelua eri materiaaleja niiden koostumuksen, rakenteen, työstön, ominaisuuksien ja suorituskyvyn perusteella, jolloin voidaan luoda perustaa ympäröivän materiaalisen maailman tuntemukselle ja kestävää kehitystä vahvistavan elämäntavan rakentamiselle (ks. Opetushallitus, 2014). Käsitteenä monimateriaalisuus voidaan nähdä mahdollisuutena hyödyntää erilaisia materiaalisia ja valmistukseen liittyviä resursseja osana osallistavaa ja tutkivaa oppimista, jossa vuorovaikutus ympäristön, materiaalin, tekijän ja toiminnan välillä auttaa rakentamaan ymmärrystä materiaalisesta maailmasta sekä hyvinvoinnista ja kestävästä elämäntavasta (Pöllänen, 2019). Näin erilaiset materiaalit samoin kuin työtavat, tekniikat ja teknologiat, työkalut, välineet ja laitteet ovat olleet ja ovat edelleen käsityön monipuolisia instrumentteja antaen mahdollisuuden tutustua monipuolisesti käsityön kaikkiin eri osa-alueisiin oppilaan kädentaitoja, avaruudellista hahmottamista ja tuntoaistia kehittäen (ks. Kokko ym., 2020; Lepistö, Rönkkö, \& Tuikkanen, 2013).

Monimateriaalisuus mahdollistaa uusimpien teknologioiden hyödyntämisen uudella tavalla osana käsityöprosessia (Kauhanen ym., 2017; Merkouris, Chorianopoulos, \& Kameas, 2017). Erilaiset tietokoneavusteiset suunnittelu- ja valmistusmenetelmät, kuten 3D-mallinnus ja -tulostus, CNC- sekä lasertyöstö mahdollistavat prototyyppien ja modernien ratkaisujen valmistamisen (Pöllänen ym., 2019). Käsityöprosessin analyyttisyyttä ja ongelmanratkaisutaitoja kehittävän ohjelmallisen ajattelun (algoritminen ajattelu, computational thinking, ks. esim. Barr \& Stephenson, 2011) luontevaa yhteyttä voidaan vahvistaa tutustumalla robotiikkaan, mikropiireihin, antureihin ja näiden ohjelmointiin (Vartiainen, Tedre, Salonen \& Valtonen, 2020a). Virtuaali- ja lisätty todellisuus (VR/AR), mallinnusohjelmat sekä dokumentaatiosovellukset mahdollistavat ratkaisujen helpon visualisoinnin ja jakamisen (ks. Pöllänen ym., 2019; Wiklund-Engblom, Hartvik, Hiltunen, Johansson, \& Porko-Hudd, 2015).

\section{Monimateriaalisuuden reunaehtoja}

\section{Kokonainen käsityö}

Perusopetuksen opetussuunnitelmissa (Opetushallitus, 2004, 2014) käsityön keskeiseksi tavoitteeksi on nostettu oppilaan ohjaaminen kokonaisen käsityöprosessin hallintaan. Kehollisena oppimisprosessina siinä korostuu 
kädentaitojen lisäksi ajattelu, pohdinta ja ongelmanratkaisu käsityöprosessin kaikissa vaiheissa (Pöllänen, 2019). Tietoisuus ja ymmärrys ympäröivästä materiaalisuudesta yhdessä oppilaan aktiivisten toimien ja muodostuvien käsitysten kanssa luovat Robert ja Michele Root-Bernsteinin (2013) mukaan mahdollisuuden oppia, ei ainoastaan ajattelemalla, vaan myös tekemällä, käyttämällä käsiä. Hallitakseen kokonaisen käsityöprosessin oppilaan tulee tutustua ja harjoitella prosessin eri vaiheita ja niissä tarvittavia tietoja ja taitoja niin yksitellen ja erikseen kuin myös yksin ja yhdessä (Kojonkoski-Rännäli, 1998; Pöllänen, 2009). Tarkoituksena on, että oppilas ideoi ja innovoi, suunnittelee, valmistaa sekä arvioi sekä tuotosta että prosessia (Pöllänen, 2019; ks. kuvio 2). Kokonaisen käsityöprosessin käynnistysvaiheessa ideoidaan ja luonnostellaan yksin tai ryhmässä oppimistehtävän teeman pohjalta ratkaisuja, jotka auttavat hahmottamaan tehtävää ja luomaan alkumielikuvaa. Saatavilla oleva informaatio, mielikuvituksen käyttö, aiemmat kokemukset ja jo olemassa olevat käsityötaidot sekä uusien taitojen harjoitteleminen tukevat alkumielikuvan synnyttämistä (Pöllänen, 2019).

Visuaalisen ja teknisen suunnittelun myötä alkumielikuva täsmentyy toimintamielikuvaksi. Tiedonhaku, uusien taitojen oppiminen, päävaiheiden ja mahdollisten tulosten analysointi sekä tasapainottelu resurssien ja rajoitteiden (mm. käyttäjä, tarkoitus, aika, materiaalit, koneet, laitteet, työkalut, taidot, kustannukset) välillä ohjaavat toimintasuunnitelman konkretisointia ja vaihtoehtoisten ratkaisujen kehittämistä (Pöllänen, 2019). Rajoitteiden lisäksi suunnitteluvaihetta tulee myös rikastuttaa liittämällä siihen erilaisia visuaaliseen tuottamiseen liittyviä tekniikoita (Laamanen, 2016; Rönkkö \& Aerila, 2015). Suunnittelua tukee myös kokeileminen, mallintaminen, protoaminen ja vuorovaikutus muiden kanssa (Pöllänen \& Urdziņa-Deruma, 2017) sekä kognitiivinen merkityksenanto, mikä sitouttaa oppilaita prosessiin (Kangas, 2014). Nimkulrat (2010) korostaa luovan prosessin ytimenä juuri dialogia materiaalin ja tekniikan tai työtavan välillä, sillä toimintojen, muotojen ja käsitteiden ajattelu tulevat vasta myöhemmin osaksi prosessia. Oppimisen näkökulmasta suunnitteluvaihetta voidaan pitää kaikkein tärkeimpänä vaiheena, sillä monet kriittiset päätökset ja ajattelua vaativat ongelmanratkaisut tehdään toimintamielikuvan rakentamisen aikana (Pöllänen, 2019).

Käsityön valmistusvaiheessa työskennellään toimintasuunnitelman mukaisesti huomioiden samaan aikaan niin resurssit ja rajoitteet kuin myös työturvallisuus (Jaatinen, Ketamo, \& Lindfors, 2017). Aikaisempien tietojen ja taitojen tarkistaminen ja rinnastaminen uusiin opittuihin asioihin kasvattavat tietokokonaisuutta ja tukevat määritellyn toimintamielikuvan toteuttamista tutkivalla otteella (Pöllänen, 2019). Tällöin mielikuva täsmentyy iteratiivisena muotoiluprosessina, jossa tarkka mielikuva syntyy tuotteen tai prototyypin ja valmistusprosessin arvioinnin, oman reflektoinnin ja saadun palautteen myötä (Kangas, 2014; Pöllänen, 2019). Luovan prosessin lopputulokseksi voi muotoutua jopa innovaatio (Lepistö ym., 2015). Sekä oman työskentelyn että valmistuvan tuotteen arviointi eri vaiheissaan on monimuotoista läpi koko käsityöprosessin ja vielä sen päättävänä vaiheena prosessin lopuksi (Saarnilahti, Lindfors, \& Iiskala, 2019). Jatkuvana prosessina kokonainen käsityö kasvattaa tekijän hiljaista tietoa sisältävää tieto- ja taitovarantoa sekä avaa reflektoinnin myötä mahdollisuuksia henkiseen kasvuun ja omien vahvuuksien havaitsemiseen 


\section{Ainedidaktiikka 5(2) (2021)}

(Pöllänen, 2015). Prosessin jatkuvuus käsityössä palauttaa tarkastelun takaisin ympäröivään rakennettuun maailmaan. Tällainen oppimisprosessi, jossa oppilaan aktiivinen toiminta ja muodostuneet käsitykset rakentuvat iteratiivisena prosessina, noudattelee niin tuotesuunnittelun (design) kehittämistavoitteita kuin insinöörisuunnittelun (engineering) optimointitavoitteita (Metsärinne \& Kallio, 2017; Pöllänen, 2009).

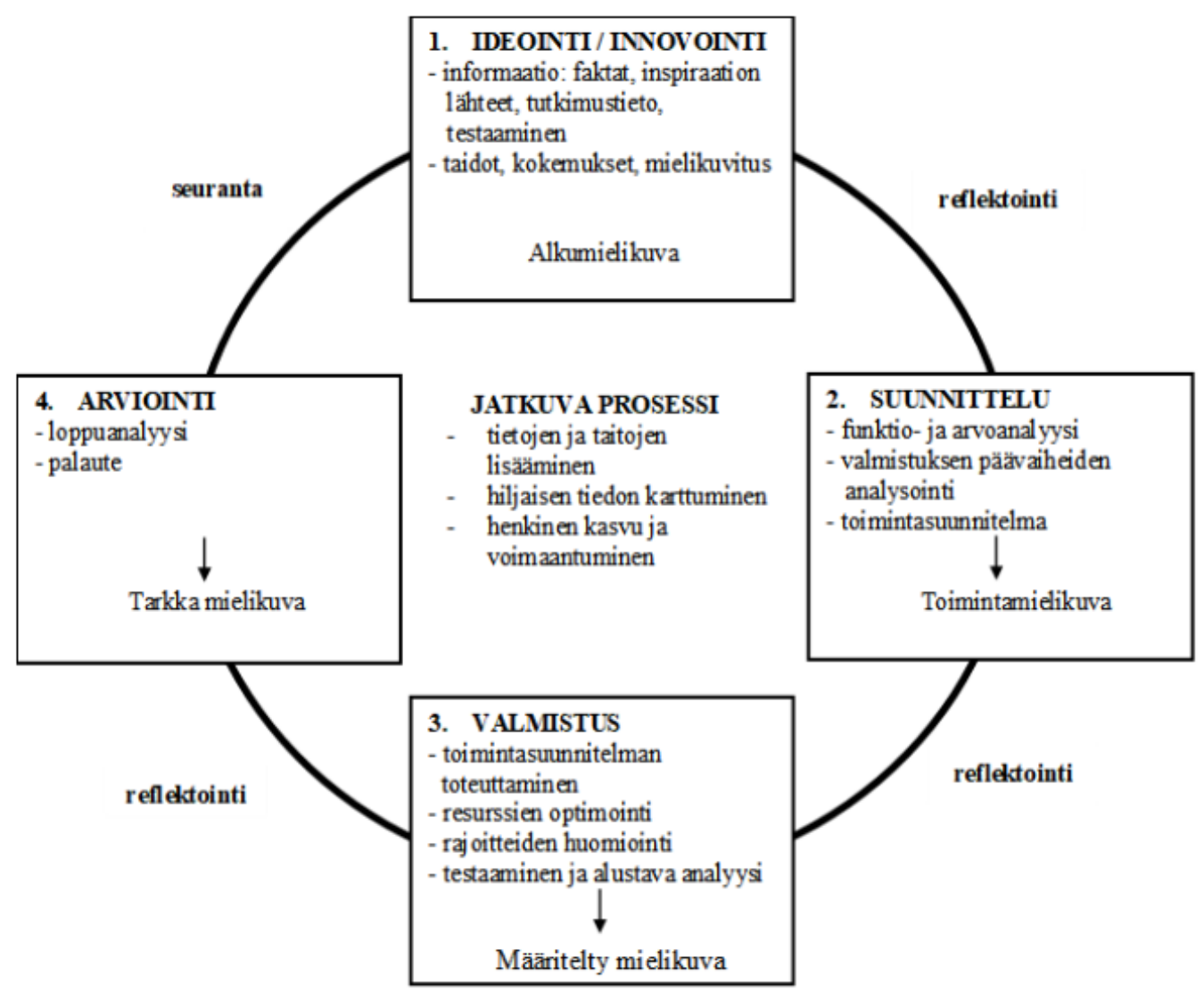

Kuvio 2. Kokonainen käsityöprosessi (Pöllänen, 2019, suomennos Pöllänen)

Kokonaisessa käsityöprosessissa monimateriaalisuus tarkoin rajaamattomana käsitteenä viittaa siihen, että käsityön opiskelu perustuu - oppilaita jaottelematta - sekä koulukäsityön perinteisten että uusien materiaalien kokeilemiseen, testaamiseen ja yhdistämiseen siten, että käsityötuote voidaan valmistaa käyttämällä perinteisiä työtapoja ja teknologioita tai hyödyntämällä uusia (Järnefelt \& Matinlauri, 2014; Lepistö ym., 2013; Pöllänen, 2019). Monimateriaalisissa käsityöprojekteissa teknisen työn sisältöinä ja vahvuuksina pidetyt teknologinen yleissivistys, digitaalitekniikka, insinöörisuunnittelu, automaatio ja robotiikka (Heinonen, 2002; Metsärinne ym., 2017; Pöllänen ym., 2019) samoin kuin tekstiilityöstä muotoiluorientaatio ja ilmaisupainotteisuus (Pöllänen, 2009, 2011) sekä molemmille yhteinen tietokoneavusteinen suunnittelu ja valmistus ovat mahdollisia kaikille oppijoille tasapuolisesti (Pöllänen ym., 2019). Koko- 
nainen käsityöprosessi voi luontevasti pohjautua itse tekemiseen, vertaisuuteen ja avoimuuteen perustuvaan maker-kulttuuriin (Oxman Ryan, Clapp, Ross, \& Tishman, 2016), jossa hyödynnetään kehittynyttä teknologiaa, globaalia tietoverkostoa, avoimen lähdekoodin ohjelmistoja, avoimia työskentelytiloja ja -ympäristöjä sekä yhteisöllisyyttä (Anderson, 2012; Kafai, 2016).

\section{Käsityön oppimisympäristöt ja yhteisopetus}

Käsityöoppiaineen historiallisen jatkumon seurauksena tekstiilityön ja teknisen työn fyysiset oppimisympäristöt (tilat, koneet, laitteet, työvälineet) eriytyvät nykyäänkin useimmissa kouluissa erilleen ja usein koulurakennuksen sisällä kauas toisistaan. Tämä on vaikeuttanut käsityötä opettavien opettajien yhteistyötä ja oppilaiden tarkoituksenmukaista siirtymistä oppimisympäristöstä toiseen (Lindfors ym., 2016). Perinteisten teknisen työn ja tekstiilityön materiaaliteknologioiden rinnalle on tullut laajeneva joukko uusia digitaalisen mallintamisen ja valmistamisen teknologioita, robotiikkaa sekä automaatioteknologiaa, joissa myös yhä useammin toteutetaan oppiainerajat ylittäviä käsityöprojekteja. Yhteisopetusta kehittämällä käsityönopettajat voivat hyödyntää vahvuuksiaan suunnitellessaan, toteuttaessaan ja arvioidessaan monimateriaalista käsityönopetusta (Jaatinen ym., 2017; Krapi, Lindfors, \& Rönkkö, 2019).

Uusia kouluja rakennettaessa tai entisiä uudistettaessa tekstiilityön ja teknisen työn oppimisympäristöjen läheisyys ja yhteisen suunnittelutilan käyttö ovat luoneet aiempaa paremmat mahdollisuudet yhteisopetukseen, jolloin opettajat ovat voineet myös monipuolistaa monimateriaalisuuden toteutuksessa pedagogisia ratkaisujaan. Eriytyneen ainedidaktisen koulutuksen saaneet käsityönopettajat, teknisen työn ja tekstiilityön opettajat, voivat yhteisopetusta hyödyntäen monipuolistaa oppilaille tarkoituksenmukaisten materiaaliteknologisten ratkaisujen toteuttamisen (Krapi ym., 2019).

Yhteisopetuksena toteutettavassa monimateriaalisessa käsityönopetuksessa valittavalla lähestymistavalla ja teknologioiden kombinaatiolla on merkitystä paitsi oppilaiden osallistamisen myös opettajien välisen työnjaon kannalta. Epäsymmetrinen työnjako ja opettajien roolien liiallinen eriytyminen saattavat aiheuttaa jommankumman opettajan liialliseen kuormitukseen ja lisätä epätasa-arvoisuuden tunnetta. Tällöin tilanne johtaa suurella todennäköisyydellä haasteisiin oppilaiden töiden etenemisessä ja voi jopa estää oppilaiden töiden valmistumisen käytettävässä aikaraamissa.

\section{Kirjallisuuskatsauksen toteutus}

Tämän kuvailevan kirjallisuuskatsauksen pragmaattisena (ks. Gutek, 2014) tavoitteena on konkretisoida esimerkein pedagogisia lähtökohtia käsityön monimateriaalisuuteen. Esimerkkien laadinnassa on integroitu useiden erilaisten mutta toisiinsa liittyvien tutkimusten tuloksia tarkasteltavan ilmiön ymmärtämiseksi ja uusien näkökulmien esiin nostamiseksi (ks. Walsh \& Downe, 2005). Kirjallisuuden avulla voidaan näin luoda 
syntetisoivia johtopäätöksiä ja sekä kehittää käytännön ohjeita (Coughlan, Cronin, \& Ryan, 2013).

Kirjallisuuskatsauksen toteutuksessa hyödynnettiin Kangasniemen ja hänen työryhmänsä (2013) muotoilemaa neljän vaiheen metodia: tutkimuskysymyksen muodostaminen, aineiston valitseminen, kuvailun rakentaminen ja tuotetun tuloksen tarkasteleminen. Nämä vaiheet etenivät iteratiivisesti tarkentuvalla metodilla, mutta samalla myös yhtäaikaisesti suhteessa toisiinsa (ks. Kangasniemi ym., 2013). Kuvailevan kirjallisuuskatsauksen mukaisesti väljä tutkimuskysymyksen muotoilu ja abduktiivinen päättely mahdollistivat ilmiön keskeisten ilmenemismuotojen hahmottamisen ja niiden välisten suhteiden havaitsemisen (ks. Salminen, 2011).

Kirjallisuuskatsauksen aineistona olleet käsityönopetusta ja monimateriaalisuutta käsittelevät artikkelit haettiin iteratiivisella hakutoimintosarjalla. Kirjallisuutta kerättiin vaiheittain taustakäsitteiden ja tutkimuskysymyksen määrittelyn jälkeen hakutarpeen muuttumatta (ks. berrypicking-metodi, ks. Bates, 1989). Tämän kirjallisuuskatsauksen tutkimustehtävän mukaisesti kansainvälisten ja kotimaisten arvioitujen tieteellisten artikkeleiden FINNA-tietokannasta haettiin kirjallisuutta, jossa esiintyivät käsityönopetukseen tai Perusopetuksen opetussuunnitelman perusteiden (2014) käsityön tavoitteisiin liittyviä käsitteitä. Hakutuloksena saatiin laaja valikoima (N 70) kirjallisuutta, jossa kuvattiin käsityötä, materialisointia sekä käsityötä ilmentävällä tavalla luovaa ilmaisua, muotoilua, teknologiaa (ml. mm. ohjelmointi, robotiikka), itsenäistä tai yhteisöllistä työskentelyä tai tutkivaa, keksivää ja kokeilevaa toimintaa. Lähilukuun perustuen pedagogisten lähtökohtien muotoilussa hyödynnetiin koko kirjallisuusjoukosta se osa kirjallisuutta (N 36), mikä vastasi parhaiten tutkimustehtävään.

Kirjallisuuden analysoinnin myötä pedagogisten lähtökohtien keskeisiä elementtejä integroitiin ja tulkittiin siten, että yksittäiset havainnot muuttuivat abduktion myötä uusiksi käsitteiksi ja tulkinnoiksi muodostaen perusteluja ja esimerkkejä (ks. Sutton, Cloves, Preston \& Booth, 2019). Tässä vaiheessa tuotettua tietoa yhdistettiin ja tiivistettiin niin, että pedagogisia lähtökohtia ilmentäviä ja erottelevia piirteitä saatiin selkeytettyä. Keskeisiksi erotteleviksi piirteiksi muotoutuivat seuraavat tekijät: miten monimateriaalisuus näyttäytyy opiskeltavana sisältönä sekä miten se välittyy oppilaille yksin tai yhdessä työskenneltäessä. Samalla aikaisempiin monimateriaalisuuden kuvauksiin (Jaatinen, Ketamo \& Lindfors, 2017; Lindfors, Marjanen \& Jaatinen; Pöllänen, 2019) perustuva pedagogisten lähtökohtien nimeäminen tarkentui. Synteesin myötä rakennetut pedagogiset lähtökohdat luovat yhden käsitteellisen rakennelman monimateriaalisuuden toteuttamisen mahdollisuuksista käsityössä.

Kuvailevan kirjallisuuskatsauksen on havaittu soveltuvan hyvin silloin, kun halutaan kuvata tutkittavaa ilmiötä mahdollisimman monipuolisesti ja tuottaa siitä kokoavaa tietoa tai tulkita uudelleen. (Awuz \& McDermott, 2017; Torraco, 2016). Tällöin sen voidaan nähdä soveltuvan erityisesti silloin, kun tarkasteltavasta aiheesta on vain vähän empiriaa tai kun aihe on haasteiden takia ajankohtainen (ks. Torraco, 2016). Menetelmänä se mahdollistaa muita kirjallisuuskatsauksia laajemman ja erilaisista metodologisista lähtökohdista tuotetun aineiston käsittelyn (Kangasniemi ym., 2013) sekä tavoitetta vastaavan raportoinnin (Torraco, 2016). 
Toisaalta tämän tyyppisen kirjallisuuskatsauksen rajoitteena voidaan pitää sitä, että vaikka se ajantasaistaa tutkimustietoa, se ei tarjoa vastaavaa analyyttistä tulosta kuin esimerkiksi systemaattinen kirjallisuuskatsaus tai meta-analyysi (Salminen, 2011). Awuz ja McDermott (2017) muistuttavat kuitenkin, että kirjallisuuskatsauksessa epätäydellinen joukko havaintoja etenee todennäköisimpien esimerkkien kuvaukseen, sillä abduktiiviselle päättelylle ominaisella tavalla johtoajatuksen läsnäolo ohjaa päättelyn tekemistä. Täten tarkastelun kohteena olevan ilmiön lähtökohtia ja teorioita voidaan käyttää ilmiöiden laadulliseen kuvaamiseen sekä perustana uusien ehdotusten kehittämiselle (Whittemore \& Knafl, 2005). Tässä kirjallisuuskatsauksessa abduktiivisen argumentaation rakentaminen toteutui useamman tutkijan 'trialogina' (ks. Paavola, 2012), jossa on kehitetty tiettyä aikaisempaa argumenttia sekä haettu ilmiötä paremmin kuvaavia tulkintoja (Torrace, 2016). Työtapana tämän voidaan nähdä lisäävän kriittistä otetta, vaikka sinällään kuvaileva kirjallisuuskatsaus ei seulo tutkimuskirjallisuutta yhtä tarkasti kuin systemaattinen katsaus (ks. Salminen, 2011).

\section{Pedagogisia lähtökohtia käsityön monimateriaali- suuteen}

Käsityössä monimateriaalisuutta voidaan tarkastella käsityön työtapojen ja teknologioiden käytön sekä opetuksen organisoinnin ja oppilaiden monimateriaalisuuden toteutumista koskevan päätöksenteon näkökulmista. Tällöin monimateriaalisuuteen liittyvät keskeiset teknologia- ja materiaalivalinnat voidaan toteuttaa kolmella eri tavalla: 1) opettajajohtoisesti, jolloin opettajat päättävät ja rajaavat monimateriaalisuuden tiettyihin tekniikoihin ja materiaaleihin, 2) suuntaa-antavasti, jolloin oppilaat tekevät valintoja opettajan asettamien rajoitusten puitteissa, tai 3) avoimista oppimistehtävistä nousevasti, jolloin opettaja antaa avoimen tehtäväksiannon ja oppilaat valitsevat osaamistaan tai prosessin aikana oppimistaan sopivat teknologiat ja materiaalit opettajien ohjatessa tarkoituksenmukaisten ratkaisujen löytämiseen.

Seuraavaksi kuvataan tieteellistä kirjallisuutta hyödyntäen esimerkinomaisesti viisi erilaista pedagogista lähestymistapaa monimateriaalisuuden toteuttamiseen perusopetuksen käsityössä. Pedagogisten lähtökohtien jaottelu perustuu aikaisempiin käsityön monimateriaalisuuden kuvauksiin (Jaatinen ym., 2017; Lindfors ym., 2016; Pöllänen, 2019), joita täydennetään ja konkretisoidaan käsityöhön ja pedagogiikkaan liittyvällä kirjallisuudella. Kunkin pedagogisen ratkaisun kuvauksessa on pyritty nostamaan esiin, miten monimateriaalisuus näyttäytyy opiskeltavana sisältönä ja miten se välittyy oppilaille yksin tai yhdessä työskenneltäessä. Vuositason suunnittelussa ideaaliratkaisu on valita erilaisia tapoja toteuttaa monimateriaalisuutta niin, että oppimistehtävissä hyödynnetään mielekkäällä tavalla käsityössä käytettäviä materiaaleja, työtapoja ja tekniikoita (ks. Jaatinen ym., 2017; Lepistö ym., 2015; Pöllänen, 2019). 


\section{Monimateriaalisuus tekstiilityön tai teknisen työn monipuolisina työ- tapoina}

Monimateriaalisuus voi toteutua monipuolisina tekstiilityön tai teknisen työn työtapoina sekä tekniikoina ja teknologioina toisistaan erillään toteutettuna laajentaen kunkin oppilaan käsityötaitoa niin, että käytettäviä materiaaleja ei määritellä etukäteen (Lepistö \& Lindfors, 2015). Työtapojen osaamisen ja materiaalituntuman laajentaminen voi kohdentua yhden materiaaliryhmän (esim. metallit, polymeerit, keraamit, kuidut, langat, kankaat, puulajit ja muut orgaaniset aineet) tai näiden yhdistelmiin niin, että samassa työssä kokeillaan, testataan ja soveltuvin osin hyödynnetään tekniikoita esimerkiksi yhdistäen puun ja metallin työstöä tai ompelua ja huovutusta (ks. Pöllänen, 2019). Materialisoidessaan ideaa aineelliseksi, fyysiseksi tuotteeksi oppilas kohtaa erilaisia haasteita (ks. Adamson, 2007; Seitamaa-Hakkarainen, 2011), jotka tukevat vastaalkajalla perustaitojen hankkimista sekä edistyneemmillä oppilailla tuotesuunnittelua ja sen kehittelyä (Pöllänen, 2009). Monimateriaalisuus voi toteutua myös ilmaisupainotteisuutena (Pöllänen, 2011), jolloin materiaalikokeilut voidaan yhdistää työtapojen ja tekniikoiden kokeiluun (esim. lankatyön eri tekniikat, puun työstäminen tai kierrätysmateriaalien käyttö).

Työskentelyä tukevassa yhteisessä teemassa oppilaan omat yksilölliset valinnat, suunnitelmat ja kokeilut ohjaavat käsityöprosessia. Monimateriaalisuuden lähtökohtana oleva teema auttaa hahmottamaan monimateriaalisuuden erilaisia ilmentymiä, vaikka oppilaat työskentelisivät omien käsityötehtäviensä parissa ja eri oppimisympäristöissä. Oppimistehtävän ideointivaiheen jälkeen oppilaat voivat siirtyä tehtävänsä mukaisesti teknisen työn tai tekstiilityön oppimisympäristöihin ja työtapoihin ja palata arviointivaiheessa yhteiseen oppimiskokemusten jakamiseen (Jaatinen ym., 2017).

\section{Monimateriaalisuus teknisen työn ja tekstiilityön materiaalirajojen ylittämisenä}

Käsityön oppimistehtävän lähtökohtana voi olla tavoite yhdistää sekä teknisen työn että tekstiilityön työtapoja ja materiaaleja samaan työhön materiaaliryhmien rajoja rikkoen. Käyttäjälähtöisen suunnittelun tai avoimen oppimistehtävän avulla voidaan rakentaa tutkivaan ja keksivään oppimiseen liittyvä haaste, jossa päätavoitteena on suunnitella ratkaisu monitieteiseen ja monimutkaiseen reaalimaailman ongelmaan (Pöllänen, 2019). Tällöin oppilaiden tavoitteena on valmistaa esimerkiksi artefakti käyttämällä soveltuvia materiaaleja, työtapoja, tekniikoita ja teknologioita. Vaikka avoimen oppimistehtävän on oltava oppilaiden omaan elämismaailmaan ja kiinnostuksen kohteisin liittyvä, tulee siinä olla myös suunnittelua helpottavia ja sitä tukevia rajoitteita (Seitamaa-Hakkarainen, Kangas, Raunio \& Hakkarainen, 2012). Opettaja voi auttaa oppilaita kohdentamaan huomionsa suunnittelun ja valmistuksen kannalta oleellisiin seikkoihin tai tukea suunnittelun lähtökohtia määrittelemällä etukäteen rajoitteiksi esimerkiksi tietyn tekniikan, käyttötarkoituksen, käyttäjän tai yllättävän materiaalin (esim. pyörän tai autonrenkaan kumi).

Oppimistehtävästä voi muotoutua laajempi projekti, jossa voidaan hyödyntää elektroniikkaa tai ohjelmointia (ks. Searle \& Kafai, 2015; Webb 
ym., 2017). Valmistettava kokonaisuus voi olla esimerkiksi älykäs heijastimena toimiva pipo tai robottiprojekti, joissa yhdistetään taide ja teknologia liikkeen, valon, äänen ja musiikin avulla (Rusk, Resnick, Berg \& Pezalla-Granlund, 2008). Käsityön uusimpien teknologioiden yhdistäminen - kuten 3D-piirtämisen ja -tulostamisen, piirto-ohjelmalla työstettyjen kappaleiden leikkaamisen laser-työstökoneella, ohjelmoinnin ja robotiikan yhdistäminen osaksi käsityötä tai erilaisten sensoreita ja ohjelmoitavia komponentteja sisältävien älykkäiden järjestelmien, tuotteiden ja e-tekstiilien suunnittelu ja valmistus - innostaa oppilaita teknologiaoppimiseen (ks. Akiva, Povis Kaleen \& Martinez, 2015; Pöllänen \& Pöllänen, 2019), tieteen ja taiteen yhdistämiseen (STEAM, ks. Burnard ym., 2017) ja luontevaan monimateriaalisuuteen (Fernaeus, Murer, Tsaknaki \& Belenguer, 2014; Katterfeldt, Dittert \& Schelhowe, 2009; Pöllänen, 2019; Weibert, Aal, von Rekowski \& Wulf, 2015).

Oppilaiden oppimistehtävä voi olla myös täysin uuden tuotteen suunnittelu (Lindfors ym., 2016). Tarkoituksena on tällöin motivoida heitä astumaan oman osaamisalueensa ulkopuolelle tutkimaan erilaisten materiaalien, tekniikoiden ja teknologioiden mahdollisuuksia (ks. Korhonen ym., 2020). Tällöin suunnitteluhaasteeseen vastaamiseksi oppilaat kehittävät visuaalisia ja teknisiä suunnitelmia sekä hankkivat tietoa ja muita resursseja suunnittelun tarkentamiseksi. Kun oppilaat ja opettaja ovat yhdessä rajanneet suunnittelutehtävän ratkaisuehdotuksesta, voivat oppilaat alkaa määritellä tarkemmin tarvittavaa osaamista, tekniikoita ja materiaaleja. Tämän iteratiivisen prosessin avulla oppilaat tutkivat, suunnittelevat uudelleen, testaavat, analysoivat ja esittelevät suunnitelmiaan ennen tuotteen valmistamista (Pöllänen, 2009). Tavoitteena on, että oppilaat saavat laajan käsityksen kokonaisesta käsityöprosessista ja kehittävät ymmärrystään monimateriaalisesta maailmasta jakamatta sitä tekniseen työhön tai tekstiilityöhön.

\section{Monimateriaalisuus erillisten käsityöprosessien kokoajana}

Monimateriaalisuuden lähtökohtana voi olla myös teknisen työn ja tekstiilityön erillisten käsityöprosessien kokoaminen. Tällöin voidaan valmistaa esimerkiksi apuväline, työkalu, mallinne tai suoja valiten sopivimmat materiaalit valmistusta ja käyttöä ajatellen. Esimerkiksi käsityöperinteeseen liittyvien tavoitteiden toteuttamisessa voidaan valmistaa nahkaesiliina tulitöihin tai työväline kehyskudontaan, kinnasneulatekniikkaan tai punonnan, nyörin ja pirtanauhan tekemiseen (ks. Pöllänen, 2019). Yksinkertaisimmat työvälineet voidaan valmistaa perinteisillä puuntyöstöön liittyvillä menetelmillä tai valitsemalla tekstiilimateriaaleista ominaisuuksiltaan sopivin. Vaativampien työvälineiden tuottamiseksi voidaan hyödyntää 3D-tulostusta tai laserleikkausta, jolloin työvälineen valmistamisesta ja sen käytöstä saadaan muodostumaan oma oppimisprosessinsa.

Sulautetut järjestelmät ja ohjelmointi voivat tukea tuotteiden suunnittelua ja valmistusta, jolloin ne tukevat monien perinteisten sekä uusien materiaalien, tekniikoiden rohkeaa ja luovaa yhdistelyä, muokkausta ja käsittelyä (Nimkulrat, 2010; Vartiainen ym., 2020a). Vaikka oppimistehtävän lähtökohta on tässä tapauksessa opettajan valmiiksi rajaama ja työskentely on rajautunut erillisiin työvaiheisiin sekä oppimisympäristöihin, voidaan valmistettavien tuotteiden suunnittelussa perehtyä kokonaista käsityöprosessia tukien erilaisiin ideointimenetelmiin ja 
suunnittelun lähtökohtiin, jotka voivat liittyä ilmaisuun, muotoiluun tai teknologiseen suunnitteluun.

\section{Monimateriaalisuus tiimeittäin yrittäjyyttä ja työelämätaitoja tuotta- vana projekteina}

Monimateriaalisuus voi käsityössä toteutua myös tiimityönä, jolloin toteutettavan oppimistehtävän keskeinen tavoite on ratkaista ongelma tai tuottaa innovaatio, johon tarvitaan tiimin jäsenten toisiaan täydentävää osaamista ja vuorovaikutusta. Tällöin oppilasryhmästä muodostetut tiimit tuottavat täydentäviä ja toisistaan eroavia vastauksia samaan oppimistehtävään. Tiimin jäsenet ovat yhteisvastuussa tuloksesta, mikä edellyttää yhdessä määriteltyä päämäärää sekä pelisääntöjä muun muassa eri henkilöiden työnjaon osalta (ks. Katzenbach \& Smith, 2015).

Oppilaiden suunnittelutehtävän tulee olla niin laaja, että se edellyttää oppilailta tiivistä yhteistyötä. Tämä suunnittelutehtävä voi olla jokin arkielämän ongelma tai kehittämishaaste (ks. Korhonen ym., 2020). Peruslähtökohtana on kuitenkin se, että ratkaisussa hyödynnetään tekstiilityön ja teknisen työn erilaisia työtapoja, teknologiaa sekä uusia rakenteellisia, materiaalisia ja toiminnallisia elementtejä (Pöllänen, 2019). Suunnitteluprosessi alkaa yhteisellä teemalla, mutta oppimisen haaste johtaa opetusryhmässä olevat tiimit erilaisiin monimateriaalisiin ratkaisuihin, jolloin tulee konkreettisesti ilmi se, että sama lähtökohta voi johtaa vaihtoehtoisiin suunnittelukriteerit täyttäviin ja tarkoitukseen sopiviin ratkaisuihin (Bereiter \& Scardamalia, 2003). Prosessin onnistumiseksi tiimin jäsenten on neuvoteltava ratkaisuun liittyvistä tekniikoista ja materiaaleista sekä keskenään että opettajan kanssa.

Suunnittelun apuna voi olla käyttäjätutkimuksen tekeminen (Goodman, Kuniavsky \& Moed, 2012), jolloin oppilaita johdatellaan tarkastelemaan käsityöprosessin ratkaisuja laajemmin kuin yksilön näkökulmasta. Projektimaiseen tiimityöhön sisältyy useita iteratiivisia prosesseja, joissa oppilaat tutkivat, etsivät tietoa, suunnittelevat uudelleen ja testaavat ja analysoivat ideoitaan teoreettisista ja käytännöllisistä näkökulmista ennen tuotteen valmistamista ja testaamista todellisessa tilanteessa (Pöllänen, 2009). Oppilaat voivat tuottaa moderneja, reaalimaailmaan soveltuva ratkaisuja. Monimateriaalisuus mahdollistaa eri teollisuuden alojen prosessien, tuotteiden, teknologioiden ja mahdollisuuksien tarkastelemisen luontevasti ja realistisesti. Oppilaat voivat toimia käsityössä yrittäjämäisesti pohtien eri materiaalien ominaisuuksia sekä esimerkiksi kustannuksia ja hintoja. Ratkaisu voi olla yhteisesti valmistettu esine, prototyyppi tai peli (esim. Pöllänen \& Vartiainen, 2013). Ryhmän jäsenet voivat valmistaa omat esineensä yhteisen suunnittelun ja testatun version mukaisesti. Pelillisyyden (esim. Tekstiilitehdas, 2019) tai sovellettujen yhteistyöhankkeiden ja liiketoimintosuunnitelmien (Studdard, Dawson \& Jackson, 2011) liittäminen tehtävään voi opettaa itseohjautuvaa yrittämistä, päätöksentekoa ja ymmärrystä liiketalousosaamisen lähtökohdista.

Prosessin aikana oppilaat esittelevät ideoitaan ja perustelujaan omassa tiimissään ja lopulta tiimit esittelevät oppimansa toisilleen (ks. Bereiter ym., 2003; Pöllänen, 2009), jolloin opitaan asioita myös niistä työtavoista, tekniikoista ja teknologioista sekä materiaaleista, joihin oma tiimi ei ole perehtynyt. Projektityöskentelyn yrittäjämäinen, ongelman- 
ratkaisuun perustuva toiminta opettaa riskien hallintaa ja johtamaan tiimin toimintaa tavoitteiden saavuttamiseksi sekä myös oppimaan epäonnistumisesta. Yhdessä tekeminen, kokeilemalla oppiminen ja kyky nähdä mahdollisuuksia kasvattavat samalla työelämätaitoja ja johdattaa oppilaat luonnollisella tavalla yli tiede- ja oppiainerajojen. Esimerkiksi konkretisoimalla ja kokoamalla luonnontieteellisissä ammateissa tarvittavaa luovuutta, tietoja ja taitoja sekä osoittamalla niiden käyttökelpoisuuden myös reaalimaailmassa ja työelämässä (vrt. Salonen ym., 2017). Tiimityössä hajaantunut asiantuntijuus tehdään näkyväksi yhteisön sujuvana ja oikea-aikaisena kommunikaationa sekä tiimityötaitojen oppiminen prosessin aikana syntyneen asiantuntijatiedon ja kokemuksen esille tuomisena (ks. Brown, Ash, Rutherford, Nakagawa, Gordon \& Campione, 1993). Kokemuksista keskustelu ja vuorovaikutus rikastavat oppilaan käsityksiä ja havaintoja ympäröivästä maailmasta (Fernström \& Kärnä-Behm, 2018). Näin oppilaat oppivat toisiltaan ja heitä voidaan tukea tunnistamaan sekä ryhmän että kunkin oppilaan omia vahvuuksia (ks. Katzenbach ym., 2015).

\section{Monimateriaalisuus yhteisöllisenä suunnittelu- ja keksimisprosessina}

Monimateriaalisia ratkaisuja voidaan toteuttaa koko koululuokan yhtenä yhteisöllisenä keksimis- ja suunnitteluhaasteena, jossa yhdistetään monipuolisesti erilaisia muotoilun, suunnittelun ja valmistamisen resursseja (ks. Korhonen ym., 2020). Yhteisöllisessä työskentelyssä yhteisöön sosiaalisesti hajaantunut asiantuntijuus (Hakkarainen, Palonen, Paavola \& Lehtinen, 2004) ja fyysiset materiaalit (Mehto, Kangas \& SeitamaaHakkarainen, 2020) tukevat yksilöiden älyllisten prosessien yhdistymistä sekä hitsautumista toisiinsa yhteiseksi voimavaraksi (Seitamaa-Hakkarainen \& Hakkarainen, 2020). Tutkiva suunnittelu (Seitamaa-Hakkarainen, 2011) ja monimateriaalisen käsityön materiaali- ja tekniikkakirjo tukevat sekä yhteisön jäsenten monipuolisen olemassa olevan osaamisen aktivoimista että työn kuluessa tapahtuvaa eriytyvää asiantuntijuutta.

Sosiaalisesti hajautetun asiantuntijuuden myötä yhteisön on mahdollista pystyä vaativampiin ja monimutkaisempiin suorituksiin kuin yksilöiden yksinään (Seitamaa-Hakkarainen ym., 2020). Yhteisöllisissä projekteissa tehtävät ovat avoimia. Ne sisältävät kyseiselle oppilasryhmälle soveltuvia keksimiseen ja avoimeen ongelmanratkaisuun liittyviä suunnitteluhaasteita, joihin on mahdollista kytkeä hyvin koulun ulkopuolisten organisaatioiden asiantuntijaosaamista ja innovaatiotoimintaa (esim. yhteissuunnittelu ja palvelumuotoilu ks. Bosch \& Matinlauri, 2020; Steen, Manschot \& de Koning, 2011; tai tekoäly ja koneoppiminen ks. Lewis \& Denning, 2018; Vartiainen, Tedre, Salonen \& Valtonen, 2020b). Konkreettinen kasvokkain työskentely asiantuntijoiden kanssa voi avata ekspertin ajattelun, tiedonkäsittelyn ja ongelmanratkaisun tapoja sekä tukea oppilaiden suunnitteluprosessien ja toimintojen oppimista monimutkaisen ongelmanratkaisun aikana (Hakkarainen, 2010). Vuorovaikutus ammattisuunnittelijan kanssa tukee oppilaiden suunnitteluprosessin hallintaa sekä nivoo suunnitteluajattelun taidot osaksi yhteisöllistä monitieteistä tiedon luomisprosessia integroituen muihin opittaviin taitoihin (Kangas, 2014). Parhaiten oppilaiden hajautettua asiantuntijuutta hyödyntävät tehtävät ovat linkitettävissä heidän omaan elämismaailmaansa ja asumisympäristöönsä (ks. Bereiter ym., 2003). Yhteisöllisessä suunnittelussa ja keksimisessä kokeneimmille oppilaille suunnattu avoin suunnitteluhaaste 
voi olla tarve uudistaa tai muuttaa jokin oman tai lähiyhteisön asuin- tai toimintaympäristö tai sen osa toimivammaksi tai viihtyisämmäksi (Bosch ym., 2020).

\section{Pohdinta}

Perusopetuksen aikana oppilaan tulisi tutustua materiaaleihin ja materiaaliteknologioihin monipuolisesti, jotta hän oppii tunnistamaan elinympäristönsä materiaaleja, osaa valmistaa, käyttää, hyödyntää ja hoitaa niitä sekä huoltaa, korjata että korjauttaa niistä valmistettuja tuotteita ekologisesti kestävällä tavalla tuotteiden elinkaarta pidentäen tai poistaa tuotteita käytöstä kiertotaloutta edistäen (ks. Väänänen \& Pöllänen, 2020). Näiden taitojen oppimisessa monen eri materiaalin käyttö yhdessä ja samassa oppimisprosessissa ei kuitenkaan ole päämäärä itsessään. Keskeisintä on kokonaisen käsityöprosessin tukeminen niin, että oppilaat ideoivat, suunnittelevat ja toteuttavat suunnitelmansa mukaisen käsityöilmaisuun, muotoiluun ja teknologiaan perustuvan käsityöprosessin ja osallistuvat aktiivisina oppijoina sen dokumentointiin ja arviointiin (Opetushallitus, 2014).

Käsityössä monimateriaalisuuden lähtökohtana ovat oppilaan kiinnostuksen kohteista nouseva ja tarkoituksenmukaisuuden huomioiva kokonainen käsityöprosessi ja siihen soveltuvat tekstiilityön sekä teknisen työn työtavat yhdessä tai toisistaan erillisinä sekä laajenevat digitaalitekniikkaan perustuvat teknologiat. Käsityön työtapoina voidaan tarkastella materialisoinnin menetelminä tekstiilityön työtapoja (mm. ompelu, lankatyöt jne.) ja teknisen työn työstötapoja (mm. lastuava, muovaava, liittäminen, pintakäsittely) toisiinsa liitettyinä tai toisistaan erillään. Monipuolinen materiaalien käyttö johdattaa myös hyödyntämään oppilaiden työskentelyssä erilaisia tekniikoita työtapojen sisällä (esim. tekstiilityössä ompelun eri tekniikat tai teknisessä työssä kappaleiden liittämisen erilaiset mahdollisuudet). Myös muun muassa mekaniikka, elektroniikka, automaatio ja erilaiset edelleen kehittyvät teknologiat ovat monimateriaalisuudessa avoimesti käytettäviä välineitä ja instrumentteja. Monimateriaalisuus toteutuu myös erilaisten materiaalien ja tekniikoiden kokeilemisena ja testaamisena. Vuositasolla monimateriaalisuutta tulisi toteuttaa siten, että se edistää laaja-alaisesti oppilaiden teknologista ymmärrystä, käsityöllisten tietojen ja taitojen oppimista ja samalla tähtää osallistavaan kestävän kehityksen periaatteiden mukaiseen toimintaan tietojen, taitojen, asenteiden ja valmistettavien tuotteiden näkökulmasta (Väänänen ym., 2020).

Tässä artikkelissa kuvatut käsityön monimateriaalisuuden pedagogiset lähtökohdat antavat esimerkinomaisesti käsityön työtavoissa hyödynnettäviä opetuksen organisointitapoja. Niihin on sisällytettävissä opetussuunnitelman perusteiden (Opetushallitus, 2014) mukaisesti ideointia, suunnittelua, kokeilua, soveltamista, dokumentointia ja arviointia sekä ylemmillä vuosiluokilla innovointia ja muotoilua työturvallisuus ja yrittäjämäinen oppiminen huomioiden. Pedagogisten ratkaisujen toteutuksessa tutkiva, keksivä ja kokeileva toiminta opetuksellisina työtapoina mahdollistaa laaja-alaisen asioiden tarkastelun, oppilaiden kiinnostuksen kohteiden huomioimisen sekä mahdollisuudet yksilölliseen työskentelyyn 
ja yhteisölliseen toimintaan (ks. Opetushallitus, 2014). Luovuuden, kriittisen ajattelun, teknologisen ja kulttuurimaailman löytämisen ja ymmärtämisen edistämisessä monimateriaalinen käsityön opetus voi näin toteutua opettajien valitsemalla tavalla erilaisista pedagogisista lähtökohdista. Oleellista opetuksessa on nostaa esiin käsityön monimateriaalisuus opiskeltavana sisältönä sekä ottaa huomioon, miten se välittyy oppilaille eri tavoin silloin, kun oppilaat työskentelevät yksin tai yhdessä. Monipuolinen käsitteellisen (mm. materiaalit ja niiden ominaisuudet) ja menetelmällisen tiedon (mm. valmistaminen, työstäminen) arviointi yhdessä oppilaiden kanssa tukee käsityössä asetettujen tavoitteiden saavuttamista (ks. Fernström ym., 2018; Lavonen, Korhonen, \& Saarinen, 2020).

Monimateriaalisuuden toteuttamisessa kouluilla on omat opetuksen organisointiin ja pedagogisiin ratkaisuihin liittyvät haasteensa. Rytivaara, Pulkkinen, Palmu ja Kontinen (2017) kuitenkin innostavat opettajia yhteisopettajuuteen, sillä se voi avustavana ja täydentävänä opettamisena, rinnakkain opettamisena tai tiimiopettamisena lisätä mahdollisuuksia opettajien omien vahvuuksien esiintuomiseen, eriyttämiseen ja opettajien omaan ammatilliseen kasvuun. Käsityössäkin yhteisopettajuutta vaikeuttaa edelleen oppimisympäristöjen erillisyys ja kuntien tiukka taloustilanne. Yhteisopettajuus voi kuitenkin tarjota yksin opettamista laajemmat mahdollisuudet monimateriaalisuuden toteuttamiseen sekä tekstiilityön että teknisen työn työtapojen hyödyntämiseen. Monimateriaalisuus on haastanut myös opettajankoulutuksen: on tarve laajentaa tulevien opettajien käsityön sisältöosaamista mutta samalla täydennyskouluttaa jo valmistuneita opettajia sekä kehittää käsityönopetusta tutkimusperustaisesti.

Keskeisenä kehitystehtävänä opetusalalla on huomioida ympäröivän maailman jatkuvat muutokset ja tämän myötä kehittää tiedon- ja taidonalat ylittävää ja yhdistävää osaamista. On havaittu, että oppilaiden tulisi työskennellä jo varhain suunnittelun ja ongelmanratkaisun sekä erilaisten teknologisten ratkaisujen ja alustojen kanssa (Foerster, 2016; Webb ym., 2017; Wing, 2016). Toisaalta useissa innovatiivisuutta tai taituruutta edellyttävissä ammateissa tarvitaan edelleen kädentaitoja sekä esimerkiksi kykyä tehdä havaintoja, muodostaa malleja ja hahmottaa asioita visuaalisesti (Root-Bernstein ym., 2013). Osaamisen ennakointifoorumin (Opetushallitus, 2019) mukaan opetuksessa tulisi huomioida niin kestävään kehitykseen kuin digitalisaatioon liittyvä osaaminen. Näiden osaamistarpeiden harjoittelussa monimateriaalisen käsityön ongelmanratkaisutehtävät tarjoavat hyvän perustan.

Käsillä oleva artikkeli on perustunut kirjallisuuskatsaukseen (ks. Coughlan ym., 2013), jolloin tarkoituksena on ollut tuoda konkretiaa monimateriaalisuuden toteuttamiseen käsityön opetuksessa, mutta myös samalla nostaa esiin, miten käsityö on luonnostaan monimateriaalista. Käsityön opetuksen taustan kuvaamisen sekä monimateriaalisuuden ja kokonaisen käsityöprosessin käsitteiden avaamisen toivotaan selkeyttävän käsityönopetuksen tilaa ja oppiaineen asemaa osana yleissivistävää perusopetusta (ks. Kokko ym., 2020). Pedagogisten lähestymistapojen toivotaan puolestaan tarjoavan monimateriaalisuudesta käytävään keskusteluun näkökulmia, joilla on sekä teoreettista että käytännöllistä merkitystä. 


\section{Ainedidaktiikka 5(2) (2021)}

Tämän kirjallisuuskatsauksen rajoitteista huolimatta voivat esitetyt pedagogiset lähtökohdat toimia esimerkkeinä ja tarjota ilmiöitä systemaattisen kirjallisuuskatsauksen tekemiseen (ks. Salminen, 2011). Aiheesta on jatkossa syytä tehdä tutkimusta myös käsityön monimateriaalisuuden toteutuksesta kertyvistä havainnoista. Käsityön opetukseen ja sen mahdollisuuksiin sekä alan käsitteistöön kohdistuvaa systemaattista analyysia tarvitaan oppiaineen ydinkäsitteiden selkeyttämiseksi.

\section{Lähteet}

Anderson, C. (2012). Makers. The New industrial revolution. New York, NY: Crown Business.

Awutzie, B. \& McDermott, P. (2017). An abductive approach to qualitative built environment research: A viable system methodological exposé. Qualitative Research Journal, 17(4), 356-372. https://doi.org/10.1108/QRJ-08-2016-0048

Barr, V. \& Stephenson, C. (2011). Bringing computational thinking to K-12: What is involved and what is the role of the computer science education community? ACM Inroads, 2(1), 48-54. https://doi.org/10.1145/1929887.1929905

Bates, M. J. (1989). The design of browsing and berrypicking techniques for the online search interface. Online Review, 13(5), 407-424. https://doi.org/10.1108/eb024320

Clavert, M. \& Kangas, K. ym. (2019). Uusi oppiaine ei ole ratkaisu teknologiaosaamisen vahvistamiseen. Lukijan mielipide. Helsingin Sanomat 24.11.2019. Luettu 25.11.2019. https://www.hs.fi/mielipide/art-2000006318716.html

Coughlan, M., Cronin, P. \& Ryan, F. (2013). Doing a literature review in nursing, health and social care. London, Thousand Oaks, New Delhi, Singapore: Sage.

Foerster, K-T. (2016). Integrating programming into the mathematics curriculum: Combining scratch and geometry in grades 6 and 7. Proceedings of the 17th Annual Conference on Information Technology Education (s. 91-96). Boston, MA: Association for Computing Machinery. https://doi.org/10.1145/2978192.2978222

Garber, E. (2002). Craft education in Finland: Definitions, rationales and the future. International Journal of Art \& Design Education, 21(2), 132-145. https://doi.org/10.1111/1468-5949.00308

Goodman, E., Kuniavsky, M. \& Moed, A. (2012). Observing the user experience. A practitioner's guide to user research. Toinen painos. Waltham, MA: Morgan Kaufmann. https://doi.org/10.1016/C2010-0-64844-9

Grönholm, P. (2019). Opettajat toivovat uutta ainetta. Helsingin Sanomat 12.11.2019, A9.

Gutek, G. L. (2014). Philosophical and ideological approaches to education. Boston: Allyn and Bacon.

Hankala-Vuorinen, M. (2019). Tekstiiliopettajaliitto peräänkuuluttaa työrauhaa uudelle opetussuunnitelmalle. Vastine Ylen uutiseen 10.11.2019. Luettu 1.12.2019. https://www.tekstiiliopettajaliitto.fi/uutiset/vastine-ylen-uutiseen-10-11-2019/

Heinonen, A. (2002). Itseohjattu ja tutkiva opiskelu teknologiakasvatuksessa: Luokanopettajakoulutuksen teknologian kurssin kehittämistutkimus. (Väitöskirja). Joensuun yliopisto.

Jaatinen, J., Ketamo, H. \& Lindfors, E. (2017). Pupil's activities in a multimaterial learning environment in craft subject: A pilot study using an experience sampling method based on a mobile application in classroom settings. Techne Series, Research in Sloyd Education and Craft Science, 24(2), 32-49. https://journals.hioa.no/index.php/techneA/article/view/1923

Järnefelt, H. \& Matinlauri, M. (2014). Käsityön opetuksen tavoitteena on herättää uteliaisuus ja rohkeus keksivään ja kokeilevaan työhön. Luettu 4.3.2019. https://www.oph.fi/ops2016/blogi/103/0/kasityon_opetuksen_tavoitteena_on_herattaa_uteliaisuus_ja_rohkeus_keksivaan_ja_kokeilevaan_kasityohon

Kafai, Y. (2016). From computational thinking to computational participation in K-12 education. Communications of the ACM, 59(8), 26-27. 


\section{Ainedidaktiikka 5(2) (2021)}

https://doi.org/10.1145/2955114

Kallio, M. \& Hilmola, A. (2019). Käsityön suosio valinnaisaineena uuden opetussuunnitelman aikana. Luettu 12.1.2020. https://www.tekninenopettaja.net/docs/Hilmola_Kallio_2019-Keskeiset tulokset kasityon_valinnoista.pdf

Kangasniemi, M., Utriainen, K., Âhonen, S-M., Pietilä, A-M., Jääskeläinen, P. \& Liikanen, E. (2013). Kuvaileva kirjallisuuskatsaus: eteneminen tutkimuskysymyksestä jäsennettyyn tietoon. Hoitotiede, 25(4), 291-301.

Kauhanen, O., Väätäjä, H., Turunen, M., Keskinen, T., Sirkkunen, E., Uskali, T. \& Karhu, J. (2017). Assisting immersive virtual reality development with user experience design approach. Teoksessa Proceedings of the 21st International Academic Mindtrek Conference (s. 127-136). New York: Association for Computing Machinery. https://doi.org/10.1145/3131085.3131126

Kojonkoski-Rännäli, S. (1998). Ajatus käsissämme. Käsityön käsitteen merkityssisällön analyysi. (Väitöskirja). Turun yliopisto.

Kokko, S. (2007). Käsityöt tyttöjen kasvatuksessa naisiksi. (Väitöskirja). Joensuun yliopisto. http://urn.fi/URN:ISBN:952-458-896-X

Kokko, S., Kouhia, A. \& Kangas, K. (2020). Finnish craft education in turbulence. Conflicting debates on the current National Core Curriculum. Techne Series, Research in Sloyd Education and Craft Science, 27(1), 1-19. https://journals.oslomet.no/index.php/techneA/article/view/3562

Krapi, S., Lindfors, E. \& Rönkkö M.-L. (2019). Käsityötä yhdessä opettaen - arvot opettajien tekemän yhteistyön pohjana. Teoksessa M. Kallio, H. Krzywacki \& S. Poulter (toim.), Arvot ja arviointi (s. 144-164). Suomen ainedidaktisen tutkimusseuran julkaisuja. Ainedidaktisia tutkimuksia. 16. Helsinki: Helsingin yliopisto, kasvatustieteellinen tiedekunta. http://hdl.handle.net/10138/308813

Laamanen, T-K. (2016). Generating and transforming representations in design ideation. (Väitöskirja). Helsingin yliopisto. http://urn.fi/URN:ISBN:978-951-51-1948-3

Lavonen, J., Korhonen, T. \& Saarinen, A. (2020). Monipuolinen arviointi tukee tavoitteiden saavuttamista. Teoksessa T. Korhonen \& K. Kangas (toim.), Keksimisen pedagogiikka (s. 218-245). Jyväskylä: PS-kustannus.

Lepistö, J. \& Lindfors, E. (2015). From gender-segregated subject to multi-material craft: Craft student teachers' views on the future of craft subject. Formakademisk, 8(4), 1-20. https://doi.org/10.7577/formakademisk.1313

Lepistö, J., Rönkkö, M.-L. \& Tuikkanen, W. (2013). Monipuolinen käsityön opetus sukupuolisen tasa-arvon toteuttajana. Käsityön aineenopettajaopiskelijoiden ja aineenopettajien kokemuksia monipuolisen käsityön opiskelusta ja käsityön sukupuolittuneisuudesta. Teoksessa S. Mahlamäki-Kultanen, T. Hämäläinen, P. Pohjonen, \& K. Nyyssölä (toim.), Maailman osaavin kansa 2020. Koulutuspolitiikan keinot, mahdollisuudet ja päämäärät (s. 98-115). Helsinki: Opetushallitus.

Lindfors, E. (2015). Master degree as a promoter of craft, design and technology education in basic education. Teoksessa M. Chatoney (toim.), Plurality and complimentary of approaches in design and technology education. Conference Proceedings, PATT29 (s. 250-255). Aix \& Marseille: Presses Universataires de Provence. https://hal.archives-ouvertes.fr/hal-01161553/file/PATT29.pdf

Lindfors, E., Marjanen, P. \& Jaatinen, J. (2016). Tyttöjen ja poikien käsityöstä monimateriaaliseksi käsityöksi. Käsityön opetusta 150 vuotta. Teoksessa M. Soininen \& T. Merisuo-Storm (toim.), Mikä mäki! Tiedäks snää? 120 vuotta opettajankoulutusta Rauman Myllymäellä (s. 81-97). Turun yliopiston opettajankoulutuslaitos, Rauman yksikkö. Turku: Turun yliopisto.

Manninen, M. \& Rissanen, M. (2019). Perusopetuksen tehtävänä on tarjota yleissivistystä, myös kädentaidoissa. Opetushallitus, blogi. Luettu 24.2.2020. https://www.oph.fi/fi/blogi/perusopetuksen-tehtavana-tarjota-yleissivistystamyos-kadentaidoissa

Marjanen, P. (2012). Koulukäsityö vuosina 1866-2003. Kodin hyvinvointiin kasvattavista tavoitteista kohti elämänhallinnan taitoja. (Väitöskirja). Turun yliopisto. http://urn.fi/URN:ISBN:978-951-29-5143-7

Marjanen, P. \& Metsärinne, M. (2019). The development of craft education in Finnish schools. Nordic Journal of Educational History, 6(1), 49-70. https://doi.org/10.36368/njedh.v6i1.124

Merkouris, A., Chorianopoulos, K. \& Kameas, A. (2017). Teaching programming in secondary education through embodied computing platforms: Robotics and 


\section{Ainedidaktiikka 5(2) (2021)}

wearables. ACM Transactions on Computing Education, 17(2), 1-22. https://doi.org/10.1145/3025013

Metsärinne, M. \& Kallio, M. (2017). Teknologiakasvatuksen oppimisalueet. Teoksessa M. Kallio, R. Juvonen, \& A. Kaasinen (toim.), Jatkuvuus ja muutos opettajankoulutuksessa (s. 180-195). Suomen ainedidaktisen tutkimusseuran julkaisuja. Ainedidaktisia tutkimuksia 12. Helsinki: Suomen ainedidaktinen tutkimusseura. http://hdl.handle.net/10138/229862

Ojanen, O. \& Rastas, J. (2019). Tekninen työ ja teknologia (TTT) - uusi oppiaine peruskouluun ja lukioon suomalaisten osaamisen turvaamiseksi. Teknisten aineiden opettajat TAO r.y. Luettu 27.11.2019. https://www.tekninenopettaja.net/docs/TTT, Tekninen tyo $\% 20$ ja teknologia.pdf

Opetushallitus. (1994). Perusopetuksen opetussuunnitelman perusteet 1994. Helsinki: Opetushallitus.

Opetushallitus. (2004). Perusopetuksen opetussuunnitelman perusteet 2004. Helsinki: Opetushallitus.

Opetushallitus. (2014). Perusopetuksen opetussuunnitelman perusteet 2014. Helsinki: Opetushallitus.

Opetushallitus. (2019). Osaaminen 2035. Osaamisen ennakointifoorumin ensimmäisiä ennakointituloksia. Helsinki: Opetushallitus. Luettu 18.2.2020. https://www.oph.fi/fi/tilastot-ja-julkaisut/julkaisut/osaaminen-2035

Oxman Ryan, J., Clapp, E. P., Ross, J. \& Tishman, S. (2016). A dispositional approach to maker-centered learning. Teoksessa K. Peppler, E. Rosenfeld \& Y.B. Kafai (toim.), Makeology. Makers as Learners (Volume 2) (s. 41-60). London: Routledge.

Paavola, S. (2012). Abduktiivinen argumentaatio: Hypoteesien hakemisen ja keksimisen välittyneet strategiat. Teoksessa J. Ritola (toim.), Tutkimuksia argumentaatiosta (s. 175-190). Turku: Turun yliopisto.

Perusopetuslaki. (1998). Perusopetuslaki 21.8.1998/628. Luettu 12.12.2019. https://www.finlex.fi/fi/laki/ajantasa/1998/19980628

Porko-Hudd, M., Pöllänen, S. \& Lindfors E. (2018). Common and holistic crafts education in Finland. Techne Series, Research in Sloyd Education and Craft Science, 25(3), 26-38. https://journals.hioa.no/index.php/techneA/article/view/3025

Pöllänen, S. (2009). Contextualising craft: Pedagogical models for craft education. International Journal of Art and Design Education, 28(3), 249-260. https://doi.org/10.1111/j.1476-8070.2009.01619.x

Pöllänen, S. (2015). Elements of crafts that enhance well-being: Textile craft makers' descriptions of their leisure activity. Journal of Leisure Research, 47(1), 58-78. https://doi.org/10.1080/00222216.2015.11950351

Pöllänen, S. (2019). Perspectives on multi-material crafts. International Journal of Art and Design Education, 39(1), 255-270. https://doi.org/10.1111/jade.12263

Pöllänen, S. \& Pöllänen, K. (2019). Beyond programming and crafts: Towards computational thinking in basic education. Design and Technology Education, 24(1), 13-32. https://ojs.lboro.ac.uk/DATE/article/view/2566

Pöllänen, S. \& Urdziṇa-Deruma, M. (2017). Future-oriented reform of craft education: The cases of Finland and Latvia. Teoksessa E. Kimonen \& R. Nevalainen (toim.), Reforming teaching and teacher education: Bright prospects for active schools (s. 117-144). Rotterdam: Sense Publishers. https://doi.org/10.1007/978-94-6300-917-1 5

Reincke, H. J. (1995). Slöjd. Die schwedische Arbeitserziehung in der internationalen Reformpädagogik.. Europäische Hochschulschriften 613. Frankfurt am Main: Peter Lang.

Root-Bernstein, R. \& Root-Bernstein, M. (2013). The art \& craft of science. Educational Leadership, 70(5), 16-21. Luettu 24.2.2015. https://www.ascd.org/el/articles/the-art-and-craft-of-science

Rytivaara, A., Pulkkinen, J., Palmu, I. \& Kontinen, J. (2017). Yhteisopetuksen työtavat sekä opettajien kokemukset ja ammatillinen kehittyminen. Teoksessa O-P. Malinen \& I. Palmu (toim.), Tavoitteena yhteisopettajuus: näkökulmia ja toimintamalleja onnistuneeseen yhdessä opettamiseen (s. 15-21). Jyväskylä: Niilo Mäki Instituutti.

Rönkkö, M-L. \& Aerila, A-J. (2015). Children Designing a Soft Toy. An LCE model as an application of the experiential learning during the holistic craft process. Techne 


\section{Ainedidaktiikka 5(2) (2021)}

serien - Forskning i Slöjdpedagogik och Slöjdvetenskap, 22(1), 44-58. https://journals.oslomet.no/index.php/techneA/article/view/988

Salminen, A. (2011). Mikä kirjallisuuskatsaus? Johdatus kirjallisuuskatsauksen tyyppeihin ja hallintotieteellisiin sovelluksiin. Opetusjulkaisuja 62, julkisjohtaminen 4. Vaasa: Vaasan yliopisto. http://urn.fi/URN:ISBN:978-952-476-349-3

Saarnilahti, S., Lindfors, E. \& Iiskala, T. (2019). Itsearviointi perusopetuksen käsityöoppiaineessa - oppilaiden käsityksiä. Teoksessa M. Rautiainen \& M. Tarnanen (toim.), Tutkimuksesta luokkahuoneisiin (s. 445-463). Suomen ainedidaktisen tutkimusseuran julkaisuja. Ainedidaktisia tutkimuksia 15. Jyväskylä: Jyväskylän yliopisto. http://hdl.handle.net/10138/298542

Salonen A., Hartikainen-Ahia A., Hense J., Scheersoi A. \& Keinonen T. (2017). Secondary school students' perceptions of working life skills in science-related careers. International Journal of Science Education, 39(10), 1339-1352. https://doi.org/10.1080/09500693.2017.1330575

Sipola, T. (2019). Teknisen työn ja tekstiilityön yhdistäminen ei lisännyt tasa-arvoa - sen sijaan se voi pahentaa ongelmaa, jota vientiteollisuus jo nyt pelkää. Yle Uutiset. 10.11.2019. Luettu 27.11.2019. https://yle.fi/uutiset/3-11031718

Sutton, A., Cloves, M., Preston, L. \& Booth, A. (2019). Meeting the review family: exploring review types and associated information retrieval requirements. Health and Information and Libraries Journal, 36(3), 202-222. https://doi.org/10.1111/hir.12276

Tekstiilitehdas. (2019). Tekstiilitehdas-oppimispeli. Opetushallitus. Luettu 18.2.2020. https://www.ubiikki.fi/tekstiili/

Torraco, R. J. (2016). Writing integrative reviews of the literature: Methods and purposes. International Journal of Adult Vocational Education and Technology, 7(3), 6270. https://doi.org/10.4018/IJAVET.2016070106

Valtioneuvosto. (2012). Valtioneuvoston asetus perusopetuslaissa tarkoitetun opetuksen valtakunnallisista tavoitteista ja perusopetuksen tuntijaosta 422/2012. Luettu 19.12.2019. https://www.finlex.fi/fi/laki/alkup/2012/20120422

Vuolas, L. (2017). "Mitä mä alan oikeesti syksyllä tekemään?”: Käsityönopettajat uuden opetussuunnitelman kynnyksellä. (Pro gradu -tutkielma). Helsingin yliopisto.

Väänänen, N. \& Pöllänen, S. (2020). Conceptualizing sustainable craft: Concept analysis of literature. The Design Journal, 23(2), 265-285. https://doi.org/10.1080/14606925.2020.1718276

Walsh, D. \& Downe, S. (2005). Meta-synthesis method for qualitative research: a literature review. Journal of Advanced Nursing, 50(2), 204-211. https://doi.org/10.1111/j.1365-2648.2005.03380.x

Whittemore, R. \& Knafl, K. (2005). The integrative review: updated methodology. Journal of Advanced Nursing, 52(5), 546-553. https://doi.org/10.1111/j.1365-2648.2005.03621.x

Wiklund-Engblom, A., Hartvik, J., Hiltunen, K., Johansson, M. \& Porko-Hudd, M. (2015). Process documentation in sloyd: Pilot study of the 'talking tools' application. International Journal of Interactive Mobile Technologies, 9(3), 1117. https://doi.org/10.3991/ijim.v9i3.4325

Wing, J. M. (2014). Computational thinking benefits society. Social Issues in Computing, $40^{\text {th }}$ Anniversary Blog. Luettu 12.8.2018. http://socialissues.cs.toronto.edu/index.html\%3Fp=279.html

\section{Kirjallisuuskatsauksen lähteet}

Adamson, G. (2007). Thinking through craft. Oxford: Berg.

Akiva, T., Povis, K. T. \& Martinez, A. (2015). Bringing in the TECH: Using outside expertise to enhance technology learning in youth programs. Afterschool Matters, Fall 2015, 45-53. Luettu 4.8.2020. http://niost.org/images/afterschoolmatters/asm 2015 fall/asm f2015 Bringing in the Tech.pdf

Bereiter, C. \& Scardamalia, M. (2003). Learning to work creatively with knowledge. Teoksessa E. De Corte ym. (toim.), Powerful learning environments: Unravelling basic components and dimensions (s. 55-68). Oxford: Pergamon.

Bosch, N. \& Matinlauri, M. (2020). Case: Design \& ProtoLab - kouluviihtyvyyttä muotoiluajattelua hyödyntäen. Teoksessa T. Korhonen \& K. Kangas (toim.), Keksimisen pedagogiikka (s. 109-120). Jyväskylä: PS-kustannus. 


\section{Ainedidaktiikka 5(2) (2021)}

Brown, A. L., Ash, D., Rutherford, M., Nakagawa, K., Gordon, A., \& Campione, J. C. (1993). Distributed expertise in the classroom. Teoksessa G. Salomon (toim.), Distributed cognitions. Psychological and educational considerations (s. 188228). Cambridge: Cambridge University Press.

Burnard, P., Dragovic, T., Jasilek, S., Biddulph, J., Rolls, L., Durning, A. \& Fenyvesi, K. (2017). The Art of co-creating arts-based possibility spaces for fostering STE(A)M practices in primary education. Teoksessa T. Chem \& X. Du (toim.), Arts-Based methods in education around the world (s. 245-279). Gistrup: River Publishers.

Fernaeus, Y., Murer, M., Tsaknaki, V. \& Belenguer, J. S. (2014). Handcrafting electronic accessories using 'raw' materials. Teoksessa Proceedings of the 8th International Conference on Tangible, Embedded and Embodied Interaction (s. 369-372). New York: Association for Computing Machinery. Luettu 25.8.2019.

http://www.mobilelifecentre.org/sites/default/files/p369-fernaeus.pdf. https://doi.org/10.1145/2540930.2567906

Fernström, P. \& Kärnä-Behm, J. (2018). Kokemuksellinen oppiminen muotoilupedagogiikan menetelmänä. Ainedidaktiikka, 2(2), 21-37. https://doi.org/10.23988/ad.64203

Hakkarainen, K. (2010). Learning communities in the classroom. Teoksessa K. Littleton, C. Wood \& J. Kleine Staarman (toim.), International handbook of psychology in education (s. 177-225). Bingley: Emerald.

Hakkarainen, K., Palonen, T., Paavola, S. \& Lehtinen, E. (2004). Communities of networked expertise: Professional and educational perspectives. Amsterdam: Elsevier.

Jaatinen, J., Ketamo, H. \& Lindfors, E. (2017). Pupil's activities in a multimaterial learning environment in craft subject: A pilot study using an experience sampling method based on a mobile application in classroom settings. Techne Series, Research in Sloyd Education and Craft Science, 24(2), 32-49. https://journals.hioa.no/index.php/techneA/article/view/1923

Kangas, K. (2014). The artifact Project. Promoting design learning in the elementary classroom. (Väitöskirja). Helsingin yliopisto. http://urn.fi/URN:ISBN:978-951-51-0401-4

Katterfeldt, E., Dittert, N. \& Schelhowe, H. (2009). EduWear: Smart textiles as ways of relating computing technology to everyday life. Teoksessa Proceedings of the International Conference on Interaction Design and Children Conference (s. 9-17). New York: Association for Computing Machinery. https://doi.org/10.1145/1551788.1551791

Katzenbach, J. R. \& Smith, D. K. (2015). The wisdom of teams: Creating the highperformance organization. Boston: Harvard Business Review Press.

Korhonen, T. \& Kangas, K. (toim.). (2020). Keksimisen pedagogiikka. Jyväskylä: PSkustannus.

Lepistö, J. \& Lindfors, E. (2015). From gender-segregated subject to multi-material craft: Craft student teachers' views on the future of craft subject. Formakademisk, 8(4), 1-20. https://doi.org/10.7577/formakademisk.1313

Lewis, G. T. \& Denning, P. J. (2018). Learning machine learning. Communications of the ACM, 61(12), 24-27. https://doi.org/10.1145/3286868

Lindfors, E., Marjanen, P. \& Jaatinen, J. (2016). Tyttöjen ja poikien käsityöstä monimateriaaliseksi käsityöksi. Käsityön opetusta 150 vuotta. Teoksessa M. Soininen \& T. Merisuo-Storm (toim.), Mikä mäki! Tiedäks snää? 120 vuotta opettajankoulutusta Rauman Myllymäellä (s. 81-97). Turun yliopiston opettajankoulutuslaitos, Rauman yksikkö. Turku: Turun yliopisto.

Mehto, V. M., Kangas, K. \& Seitamaa-Hakkarainen, P. (2020). Materiality constraining and enabling collaboration in secondary school maker centered learning. Teoksessa M. Gresalfi \& I. S. Horn (toim.), The Interdisciplinarity of the Learning Sciences, 14th International Conference of the Learning Sciences (ICLS) 2020, Volume 2 (s. 825-826). Nashville, Tennessee: International Society of the Learning Sciences. https://repository.isls.org/handle/1/6783

Nimkulrat, N. (2010). Material inspiration: From practice-led research to craft art education. Craft Research Journal, 1(1), 63-84.

https://doi.org/10.1386/crre.1.63_1 


\section{Ainedidaktiikka 5(2) (2021)}

Pöllänen, S. (2009). Contextualising craft: Pedagogical models for craft education. International Journal of Art and Design Education, 28(3), 249-260. https://doi.org/10.1111/j.1476-8070.2009.01619.x

Pöllänen, S. (2011). Beyond craft and art: A pedagogical model for craft as selfexpression. International Journal of Education through Art, 7(2), 111-125. https://doi.org/10.1386/eta.7.2.111_1

Pöllänen, S. (2019). Perspectives on multi-material crafts. International Journal of Art and Design Education, 39(1), 255-270. https://doi.org/10.1111/jade.12263

Pöllänen, S. \& Pöllänen, K. (2019). Beyond programming and crafts: Towards computational thinking in basic education. Design and Technology Education, 24(1), 13-32. https://ojs.lboro.ac.uk/DATE/article/view/2566

Pöllänen, S. \& Vartiainen, L. (2013). Forest-themed learning games as a context for learning via collaborative designing of crafts. Techne Series, Research in Sloyd Education and Craft Science, 20(3), 33-49. https://journals.oslomet.no/index.php/techneA/article/view/709/

Rusk, N., Resnick, M., Berg, R. \& Pezalla-Granlund, M. (2008). New pathways into robotics: Strategies for broadening participation. Journal of Science Education and Technology, 17(1), 59-69. https://doi.org/10.1007/s10956-007-9082-2

Searle, K. A. \& Kafai, Y. B. (2015). Boy's needlework: Understanding gendered and indigenous perspectives on computing and crafting with electronic textiles. Teoksessa Proceedings from ICER'15: The eleventh annual International Conference on International Computing Education Research (s. 31-39). New York: Association for Computing Machinery. https://doi.org/10.1145/2787622.2787724

Seitamaa-Hakkarainen, P. (2011). Design based learning in crafts education: Authentic problems and materialization of design thinking. Teoksessa H. Ruismäki \& I. Ruokonen (toim.), Design Learning and well-being. 4th International Journal of Intercultural Arts Education (s. 3-27). Helsinki: University of Helsinki. http://hdl.handle.net/10138/28078

Seitamaa-Hakkarainen, P. \& Hakkarainen, K. (2020). Yhdessä oppiminen ja sen tukeminen. Teoksessa T. Korhonen \& K. Kangas (toim.), Keksimisen pedagogiikka (s. 132-140). Jyväskylä: PS-kustannus.

Seitamaa-Hakkarainen, P., Kangas, K., Raunio, A-M., \& Hakkarainen, K. (2012). Collaborative design practices in technology mediated learning. Design and Technology Education: an International Journal, 17(1), 54-65. https://ojs.lboro.ac.uk/DATE/article/view/1687/

Steen, M., Manschot, M. \& de Koning, N. (2011). Benefits of co-design in service design projects. International Journal of Design, 5(2), 53-60. http://www.ijdesign.org/index.php/IJDesign/article/view/890/

Studdard, N I., Dawson, M. \& Jackson, N. L. (2013). Fostering entrepreneurship and building entrepreneurial self-efficacy in primary and secondary education. Creative and Knowledge Society, 3(2), 1-14. https://doi.org/10.2478/v10212-011-0033-1

Vartiainen, H., Tedre, M., Salonen, A. \& Valtonen, T. (2020a). Rematerialization of the virtual and its challenges for design and technology education. Techne Series. Research in Sloyd Education and Craft Science, 27(1), 52-69. https://journals.hioa.no/index.php/techneA/article/view/3558

Vartiainen, H., Tedre, M., Salonen, A. \& Valtonen, T. (2020b). Learning machine learning with very young children: Who is teaching whom? International Journal of Child-Computer Interaction, 25. https://doi.org/10.1016/j.ijcci.2020.100182

Webb, M., Davis, N., Bell, T., Katz, Y. J., Reynolds, M. N., Chambers, D. P. \& Syslo, M. M. (2017). Computer science in K-12 school curricula of the 21st century: Why, what and when? Education and Information Technologies, 22(2), 445-468. https://doi.org/10.1007/s10639-016-9493-x

Weibert, A., Aal, K., von Rekowski, T. \& Wulf, V. (2015). 'Hey, can we make that, please?": On craft as a means to cross-cultural community-building. The Journal of Community Informatics, 11(2). https://doi.org/10.15353/joci.v11i2.2841 